\title{
The BH3 mimetic drug ABT-737 induces apoptosis and acts synergistically with chemotherapeutic drugs in thyroid carcinoma cells
}

\author{
Martina Broecker-Preuss ${ }^{1,3^{*}}$, Nina Becher-Boveleth ${ }^{1,4}$, Stefan Müller ${ }^{2}$ and Klaus Mann ${ }^{1,5}$
}

\begin{abstract}
Background: Patients with dedifferentiated and anaplastic thyroid carcinomas that do not take up radioiodine are resistant to chemotherapeutic treatment and external irradiation and thus are difficult to treat. Direct induction of apoptosis is a promising approach in these apoptosis-resistant tumor cells. The BH3 mimetic ABT-737 belongs to a new class of drugs that target anti-apoptotic proteins of the BCL-2 family and facilitate cell death. The purpose of this study was to investigate the effect of ABT-737 alone or in combination with chemotherapeutic drugs on thyroid carcinoma cell lines.
\end{abstract}

Methods: A total of 16 cell lines derived from follicular, papillary, and anaplastic thyroid carcinomas were treated with ABT-737. Cell viability was measured with MTT assay. Cell death was determined by cell cycle phase distribution and subG1 peak analyses, determination of caspase 3/7 activity and caspase cleavage products, lactate dehydrogenase (LDH) liberation assays and LC3 analysis by western blot.

Results: The number of viable cells was decreased in all cell lines examined after ABT-737 treatment, with IC50 values ranging from 0.73 to $15.6 \mu \mathrm{M}$. Biochemical markers of apoptosis like caspase activities, caspase cleavage products and DNA fragmentation determined as SubG1 peak were elevated after ABT-737 treatment, but no LC3 cleavage was induced by ABT-737 indicating no autophagic processes. In combination with doxorubicin and gemcitabine, ABT-737 showed synergistic effects on cell viability.

Conclusions: With these experiments we demonstrated the efficacy of the $\mathrm{BH} 3$ mimetic drug ABT-737 against dedifferentiated thyroid carcinoma cells of various histological origins and showed synergistic effects with chemotherapeutic drugs. ABT-737-treated cells underwent an apoptotic cell death. ABT-737 and related BH3 mimetic drugs, alone or in combination, may thus be of value as a new therapeutic option for dedifferentiated thyroid carcinomas.

Keywords: Apoptotic cell death, Dedifferentiated thyroid carcinoma, BCL-2 inhibitor, Thyroid cancer

\section{Background}

Follicular cell derived thyroid cancer is the most common malignant endocrine neoplasm and can be classified into well differentiated thyroid cancer subtypes (about $90 \%$ ) and poorly differentiated or anaplastic subtypes (about

\footnotetext{
*Correspondence: martina.broecker@uni-due.de

${ }^{3}$ Present Address: Department of Clinical Chemistry, University Hospital Essen, Hufelandstr. 55, Essen, Germany

Full list of author information is available at the end of the article
}

$10 \%)[1-3]$. Of the differentiated carcinomas, $85-90 \%$ are papillary thyroid carcinoma (PTC) and $10-15 \%$ are follicular thyroid carcinoma (FTC). Most differentiated carcinomas are indolent tumors that progress slowly, and can be treated with thyroidectomy and radioiodine ablation [4]. However, in 10-15\% of patients initially diagnosed with differentiated carcinomas the tumor behaves aggressively and there is currently no effective treatment strategy since tumor dedifferentiation is accompanied by a reduction in radioiodine uptake and storage [4-6]. 
Anaplastic (undifferentiated) thyroid carcinomas (ATC) are highly aggressive and lethal tumors that depict highly infiltrative growth and have completely lost the ability to take up iodine [7]. Poorly differentiated thyroid carcinomas (PDTC) represent an intermediate between ATC and well-differentiated thyroid carcinomas with reduced ability of radioiodine uptake [8]. Besides their aggressive growth, the loss of the ability to take up radioiodine makes both PDTC and ATC difficult to treat, and contributes to the poor patient's prognosis. Conventional chemotherapeutic treatment is ineffective against aggressive thyroid carcinomas $[9,10]$ and points to the inability of dedifferentiated thyroid cancer cells to undergo chemotherapy-induced cell death [11]. Facilitating cell death induction in these carcinoma cells thus is one new therapeutic option.

Resistance to cell death and the imbalance between cell division and cell death pathways contributes to uncontrolled tumor proliferation and is one characteristic feature of cancer cells and contributes to the "hallmark of cancer cells" [12]. Therapies that restore the ability of tumor cells to undergo apoptosis therefore are a promising new treatment opportunity.

In general, cell death can be induced by different signalling pathways and it morphologically and biochemically mainly appears as apoptosis, necrosis, necroptosis, and autophagy (review: [13]). According to the Nomenclature Committee on Cell Death [14], apoptosis is a form of regulated cell death characterized by the activation of caspases, a family of cysteine proteases [15]. Caspase activation results in degradation of various intracellular substrates, the fragmentation of nuclear DNA, and, in turn, to characteristic morphological changes of the affected cells [14]. Cells undergoing necrosis show cell swelling, early plasma membrane permeabilisation followed by cell rupture and the release of cellular material (review: [16]). The regulated form of necrosis is called necroptosis [17]. Autophagy at the other hand is characterized by self-digestion and thus recycling of cellular components. Thus, autophagy is also a survival mechanism for the whole cell population in situations like starvation or cellular damage (review: [18]).

Apoptosis is initiated by two signalling pathways, the extrinsic or death receptor pathway which is activated by binding of extracellular ligands of the tumor necrosis factor family to death receptors, and the intrinsic or mitochondrial pathway, which is regulated by proteins of the B-cell lymphoma (BCL-2) family (review: [13]). This protein family consists of pro-survival proteins like BCL-2, MCL1 and BCL-xL, initiator BCL2 homology(BH3)-only proteins like PUMA, BIM and NOXA, and the cell death mediator proteins like BAX and BAK. The proteins of the BCL-2 family interact with each other by dimerization and apoptosis is initiated by BAX and BAK homo- or heterodimers. To prevent apoptosis, the prosurvival members like BCL-2 form heterodimers with BAX and BAK [19]. Stress signals like DNA damage lead to the activation of $\mathrm{BH} 3$-only proteins which bind BCL-2 to liberate BAX and BAK and thus induce apoptosis [20].

$\mathrm{BH} 3$ mimetics are a new class of cancer therapeutics that mimic the binding of $\mathrm{BH} 3$-only proteins to the hydrophobic groove of anti-apoptotic proteins [21]. In turn, heterodimerization of anti-apoptotic proteins with pro-apoptotic proteins is prevented and pro-apoptotic proteins are able to dimerize and trigger cell death [22]. ABT-737 is a BH3 mimetic that binds to and inhibits BCL-2, BCL-xL and BCL-w with high affinity but has a lower binding to MCL1 [23]. Consistent with its mechanism of action, the ability of ABT-737 to kill cells is dependent on the presence of BAK or BAX in the cell [24]. ABT-737 and its orally available analogue ABT-236 [25] already showed preclinical efficacy in some tumor cell models and are currently tested in clinical studies [26-30].

Based on the importance of BCL-2 proteins for apoptosis and for the therapy resistance of cancer cells, we studied the effect of the BH3 mimetic ABT-737 on proliferation and cell death induction in different thyroid carcinoma cell lines alone and in combination with chemotherapeutic drugs. With these experiments we verified the suitability of ABT-737 as a potential new therapeutic option for dedifferentiated thyroid carcinomas.

\section{Results}

ABT-737 decreased viability of thyroid carcinoma cells

Sixteen cell lines from FTC, PTC and ATC were treated with increasing concentrations of ABT-737 or vehicle for $48 \mathrm{~h}$ and the percentage of viable cells compared to controls was assessed. Treatment with ABT-737 decreased the number of cells in all 16 thyroid carcinoma cell lines analyzed, although to a variable degree (Table 1). IC50 values were in a relatively wide range of concentration $(0.73-15.6 \mu \mathrm{M})$ with most values (12 of 16) between 1.0 and $5.0 \mu \mathrm{M}$. The lowest IC50 value of $0.73 \mu \mathrm{M}$ was found in the B-CPAP PTC cell line, while three cell lines had IC values $>10 \mu \mathrm{M}$ (RO82W FTC cell line: $15.6 \mu \mathrm{M}$, 8305 and 8505 ATC cell lines: 10.9 and $10.1 \mu \mathrm{M}$; Table 1 ). IC50 values $<2.0 \mu \mathrm{M}$ were found in FTC and PTC cell lines. However, two cell lines derived from FTC (FTC238 and RO82W) depicted higher IC50 values (3.32 and $15.6 \mu \mathrm{M})$. In contrast, all IC50 values in ATC cell lines were $>2.0 \mu \mathrm{M}$ with SW1736, HTh7 and HTh74 cells being the most sensitive ATC cell lines (Table 1). As examples, results for FTC236, BHT101, SW1736, HTh83 and 8305 cells are shown in Fig. 1. Overall, the ABT-737 treatment decreased the quantity of viable cells in all 16 thyroid 
Table 1 Origin and IC50 values of all thyroid carcinoma cell lines after $48 \mathrm{~h}$ of treatment with increasing concentrations of ABT-737 (MTT assay)

\begin{tabular}{lll}
\hline Cell line & Origin & IC50 ABT-737 $(\boldsymbol{\mu M})$ \\
\hline FTC133 & FTC & $1.31 \pm 0.09$ \\
FTC236 & FTC & $1.71 \pm 0.13$ \\
FTC238 & FTC & $3.32 \pm 0.25$ \\
ML1 & FTC & $1.24 \pm 0.12$ \\
TT2609 & FTC & $1.30 \pm 0.10$ \\
RO82W & FTC & $15.6 \pm 1.12$ \\
BHT101 & PTC & $1.20 \pm 0.09$ \\
B-CPAP & PTC & $0.73 \pm 0.08$ \\
TPC-1 & PTC & $1.79 \pm 0.13$ \\
SW1736 & ATC & $2.05 \pm 0.18$ \\
C643 & ATC & $4.89 \pm 0.34$ \\
HTh7 & ATC & $2.39 \pm 0.21$ \\
HTh74 & ATC & $2.27 \pm 0.19$ \\
HTh83 & ATC & $4.10 \pm 0.37$ \\
8305 & ATC & $10.9 \pm 0.93$ \\
8505 & ATC & $10.1 \pm 1.03$ \\
\hline
\end{tabular}

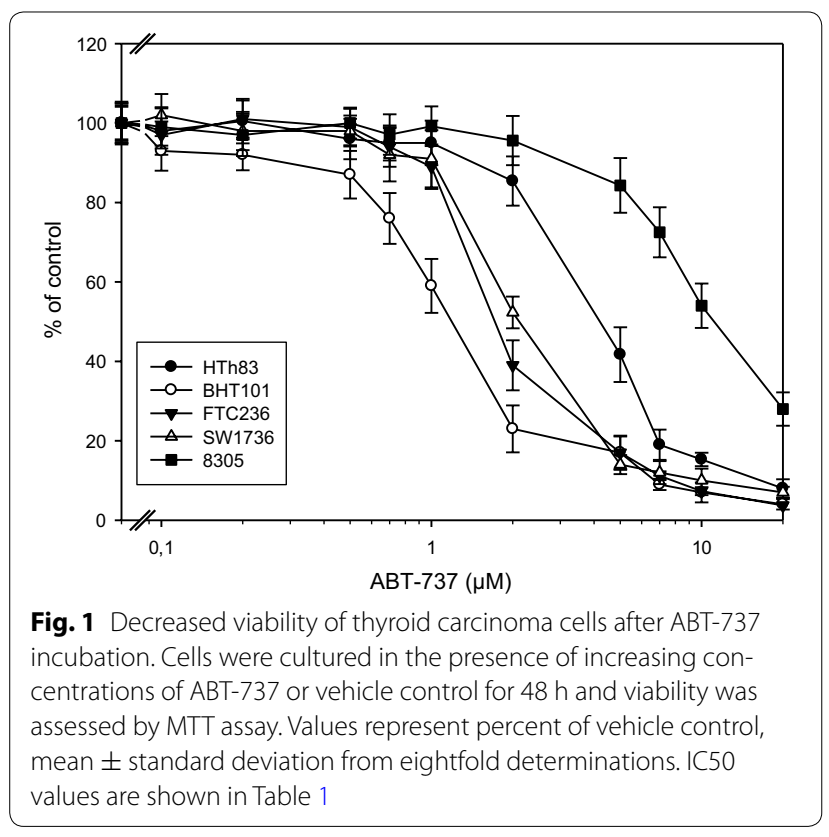

carcinoma cell lines examined. The IC50 values for ABT737 treatment ranged between 0.73 and $>10 \mu \mathrm{M}$ with a slightly better effect in most of the more differentiated FTC and PTC cell lines.

\section{Cell cycle analyses after ABT-737 treatment}

Cell cycle analyses and the other experiments to determine the kind of cell death caused by ABT-737 were performed in five cell lines of different histological origin with similar IC50 values: ML1 and FTC236 cells were derived from FTC, BHT101 cells were derived from PTC and SW1736 and HTh7 from ATC. Cell cycle analyses of the propidium iodine stained DNA depicted a significant increase of cells in subG1 fraction in all five cell lines analyzed, pointing to ABT-737-induced cell death and DNA fragmentation (Table 2; Fig. 2). Interestingly, the percentage of cells in subG1 peak was the highest in ABT-737-treated papillary BHT101 and anaplastic SW1736 cells (54.8 and $39.9 \%$; Table 2). Both cell lines were shown to harbor a BRAF V600E mutation that in thyroid tumors is found exclusively in carcinomas derived from PTC and which indicates that the ATC from which the SW1736 cells are derived originated as a PTC [31, 32]. Follicular ML1 and FTC236 cells and the anaplastic HTh7 cell line showed significantly increased values for the percentage of cells in subG1 peak of around $20 \%$ after ABT-737 treatment (21.2; 18.8 and $20.1 \%$; Table 2). The remaining living cells from all five cell lines depicted a significant increase in the percentage of cells in the S phase of the cell cycle with $37.1-44.5 \%$ of all living cells resting in $\mathrm{S}$ phase, while the percentage of cells in the G1 and G2/S-phase was diminished (Table 2).

\section{Cell death after ABT-737 treatment}

The kind of cell death induced by ABT-737 was analyzed biochemically in the five cell lines. To prove apoptotic cell death mechanisms after ABT-737 treatment, caspase 3 and 7 activity measurements and the increases in cleaved caspase 3 and cleaved PARP as products of activated caspases were analyzed. Caspase activities were significantly elevated after $24 \mathrm{~h}$ of ABT-737 treatment in all five thyroid carcinoma cell lines examined (Fig. 3a). ML1 cells exhibited the highest increase (412\% of control after $24 \mathrm{~h}$ ), while in FTC236, BHT101, SW1736 and HTh7 cells, the increase in caspase $3 / 7$ activities were between $338 \%$ (SW1736) and $376 \%$ (HTh7) of vehicle-treated control. Significant increases in cleaved caspase 3 (Fig. 3b) and cleaved PARP (Fig. 3c) as results of activated caspases were verified by specific ELISA analyses in all ABT-737treated cells. Both increases were of the same magnitude in all five cell lines (374-466 \% of control for cleaved caspase 3, Fig. 3b and 312-425 \% of control for cleaved PARP, Fig. 3c) with ML1 cells being the most sensitive cell line. Moreover, LDH activity in supernatants of ABT-737treated cells was significantly elevated in all five cell lines (188-265 \% of control, Fig. 3d) indicating cell death by a disruption of cell membranes by necrosis or secondarily to apoptosis or other kinds of cell death. Taken together, our results of the DNA fragmentation depicted as SubG1 peak in cell cycle analyses, together with the increase in caspase activation after ABT-737 treatment pointed to an activation of the apoptosis machinery in treated cells. 
Table 2 Distribution of cell cycle phases in vehicle-treated and ABT-737-treated thyroid carcinoma cells (24 h, $1 \mu \mathrm{M})$

\begin{tabular}{|c|c|c|c|c|c|}
\hline Cell line & Treatment & $\%$ subG1 & $\%$ G1 & $\%$ G2/M & $\% \mathrm{~S}$ \\
\hline \multirow[t]{2}{*}{ ML1 (FTC) } & Untreated & $0.39 \pm 0.1$ & $37.5 \pm 2.1$ & $30.5 \pm 2.4$ & $32.0 \pm 2.2$ \\
\hline & 24 h ABT-737 & $21.2 \pm 2.9^{*}$ & $34.0 \pm 3.1$ & $21.5 \pm 1.9^{*}$ & $44.5 \pm 3.6^{*}$ \\
\hline \multirow[t]{2}{*}{ FTC236 (FTC) } & Untreated & $0.21 \pm 0.1$ & $48.5 \pm 4.4$ & $24.1 \pm 1.6$ & $27.4 \pm 2.0$ \\
\hline & 24 h ABT-737 & $18.8 \pm 2.0^{*}$ & $41.6 \pm 3.9$ & $20.3 \pm 2.6$ & $38.1 \pm 2.9^{*}$ \\
\hline \multirow[t]{2}{*}{ BHT101 (PTC) } & Untreated & $3.16 \pm 2.8$ & $65.1 \pm 5.3$ & $16.0 \pm 1.7$ & $18.9 \pm 2.3$ \\
\hline & 24 h ABT-737 & $54.8 \pm 4.6^{*}$ & $42.6 \pm 5.3^{*}$ & $16.1 \pm 2.7$ & $41.3 \pm 5.0^{*}$ \\
\hline \multirow[t]{2}{*}{ SW1736 (ATC) } & Untreated & $1.52 \pm 0.4$ & $54.9 \pm 5.4$ & $15.2 \pm 2.2$ & $29.9 \pm 2.6$ \\
\hline & 24 h ABT-737 & $39.9 \pm 5.9^{*}$ & $42.8 \pm 4.5^{*}$ & $13.2 \pm 1.2$ & $44.0 \pm 3.6^{*}$ \\
\hline \multirow[t]{2}{*}{ HTh7 (ATC) } & Untreated & $3.10 \pm 0.2$ & $60.1 \pm 4.9$ & $10.6 \pm 0.8$ & $29.3 \pm 2.6$ \\
\hline & 24 h ABT-737 & $11.1 \pm 1.4^{*}$ & $59.6 \pm 4.7$ & $3.3 \pm 0.4^{*}$ & $37.1 \pm 2.6^{*}$ \\
\hline
\end{tabular}

Values for G1-, G2/M- and S-phase are determined for the living cells that were not included in the sub-G1-peak

* Indicates significant change ( $p<0.05$, Student's t test) compared to controls treated with vehicle

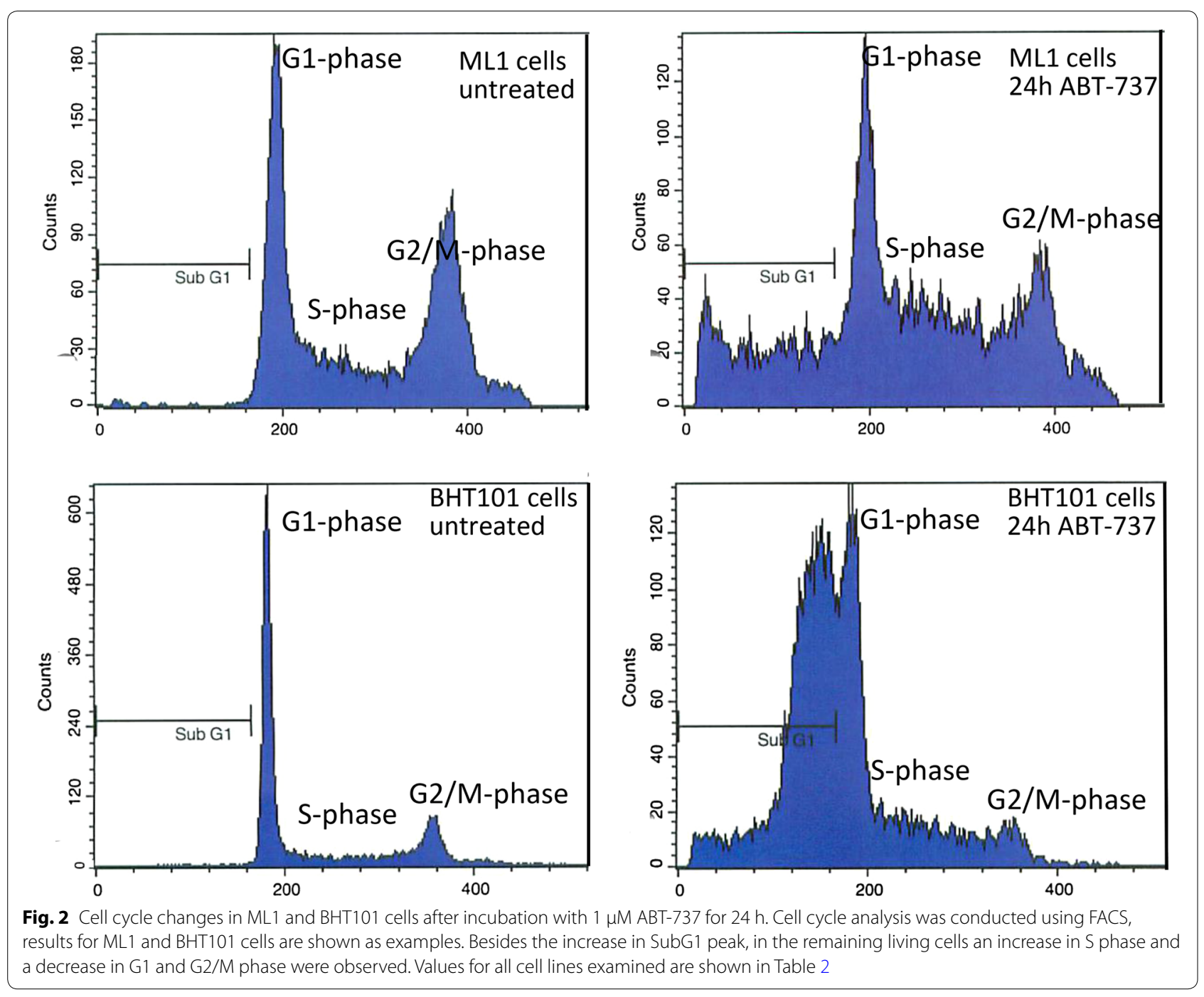




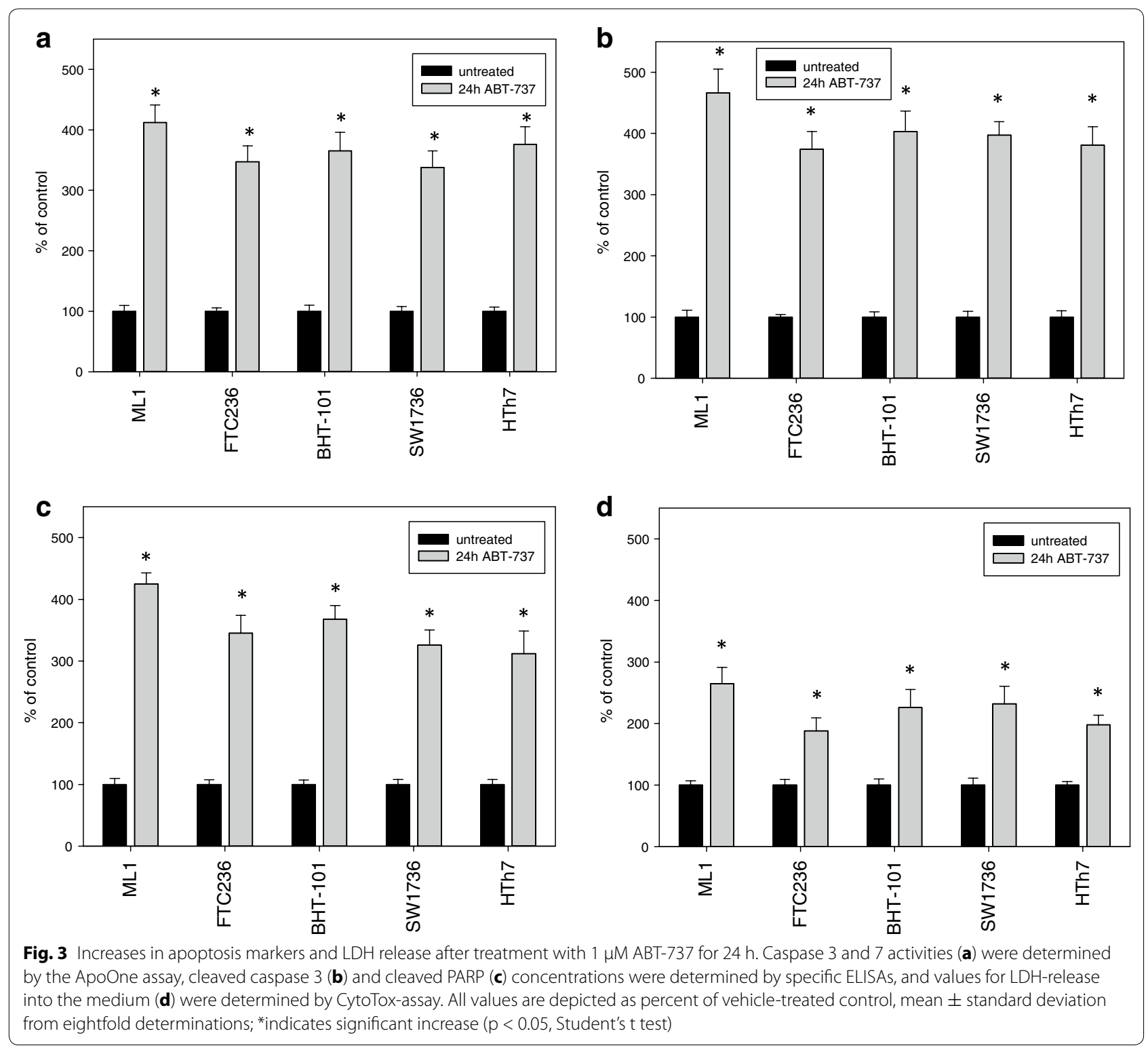

Furthermore, LC3B conversion as a marker of autophagic cell death was examined by western blot analyses after ABT-737 treatment to exclude the involvement of autophagic processes. As expected, all five thyroid carcinoma cells showed no LC3B cleavage while HepG2 cells treated with obatoclax which were used as positive control [33] depicted a clear conversion of LC3B isoforms (Fig. 4).

\section{Synergistic action of ABT-737 with chemotherapeutic agents}

The effects of a combined treatment of thyroid carcinoma cells with ABT-737 and different chemotherapeutic agents (doxorubicin, gemcitabine, and cisplatin) on the survival rates of five thyroid carcinoma cell lines were investigated to study the possibility of a synergistic effect. The results are shown in Table 3. Calculation of survival rates according to the method of Drewinko et al. [34] yielded synergistic effects $(\mathrm{Cl}$ values $>1.05)$ in three of five cell lines (FTC236, ML1, SW1736) for the combination of ABT-737 with doxorubicin, while BHT101 and HTh7 cells showed additive effects of both substances (Table 3a). For the combination of ABT-737 with gemcitabine, in four out of five cell lines synergism was observed, while papillary BHT101 only showed an additive effect (Table $3 \mathrm{~b}$ ). In combination with cisplatin, ABT-737 acted additively in all five cell lines (Table 3c). No antagonistic effect was observed (Table 3). 


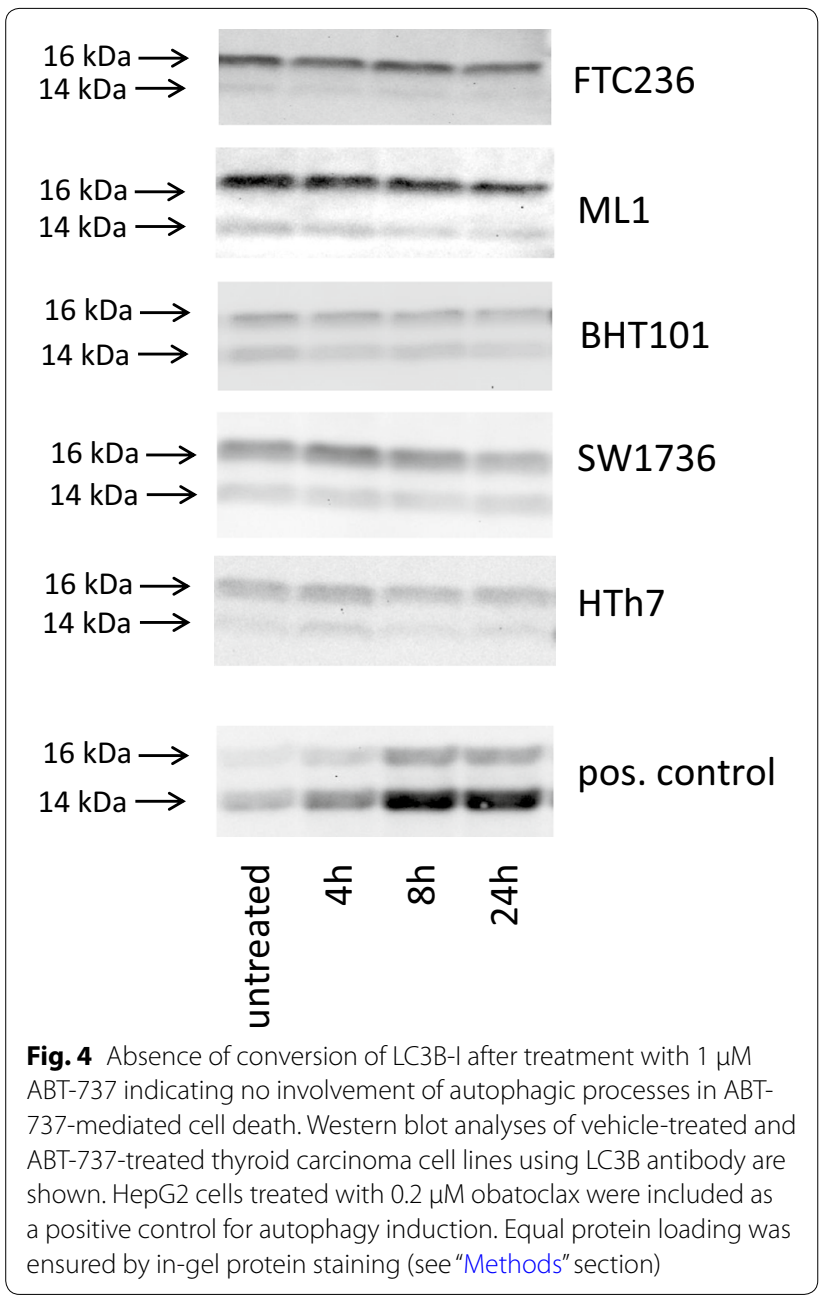

\section{Discussion}

With our experiments we showed the efficacy of the BH3 mimetic drug ABT-737 in reducing the number of viable cells and in inducing apoptotic cell death in thyroid carcinoma cells of various histological origins.

Patients with dedifferentiated and anaplastic thyroid carcinomas are difficult to treat since during dedifferentiation thyroid carcinoma cells lose their ability to take up radioiodine. Furthermore, thyroid carcinoma cells are resistant to external radiation and chemotherapeutic treatment [4]. The inability of these cells to undergo apoptotic cell death is one reason for this resistance [12, 13] and may be influenced by a new class of pharmacological compounds termed BH3 mimetics [23, 35]. BH3 mimetic drugs, such as ABT-737, are due to counter apoptotic blocks by binding to anti-apoptotic proteins like BCL-2, BCL-xL and BCL-w [23, 24]. In preclinical studies, ABT-737 showed single agent efficacy against some tumor types like small cell lung cancer, follicular lymphoma and chronic lymphocytic leukemia [36-38].
Some recently completed phase 1 trials with ABT-263, the orally available analogue drug of ABT-737, also showed clinical responses in $30-50 \%$ of patients with chronic lymphocytic leukemia (CLL) $[26,27]$ but not in small cell lung cancer (SCLC) patients [28].

In this study we showed that ABT-737 is also active against dedifferentiated and anaplastic thyroid carcinoma cells by inducing apoptotic cell death. ABT-737 reduced the number of viable cells in all 16 thyroid carcinoma cell lines investigated. All IC50 concentrations measured, except that of B-CPAP cells $(0.73 \mu \mathrm{M})$ were above $1 \mu \mathrm{M}$ but in a relatively narrow range (up to $15.6 \mu \mathrm{M}$ ). IC50 values found in this study were thus in the range already reported for lymphoma [36], leukaemia [39] and glioblastoma cells [40]. However, IC50 values were higher than those of extremely sensitive primary CLL cells with IC50 values in the low nanomolar range [41] and in a subset of SCLC cell lines which exhibited IC50 values $<0.1 \mu \mathrm{M}[23$, 37, 38].

Our biochemical data in ABT-737-treated thyroid carcinoma cells argue for an apoptotic cell death with activation of caspases, increase in caspase cleavage products and DNA fragmentation. An increased LDH release after ABT-737 treatment probably due to cell death by secondary necrosis was seen in all five cell lines examined. These data fit well with the proposed mechanism of action of ABT-737. It was shown that ABT-737 mimics the action of the BH3-only protein BAD by binding the anti-apoptotic proteins BCL-2, BCL-xL and BCL-w and inhibits its function so that apoptosis can be induced [23]. Induction of autophagy by ABT-737 by disrupting the interaction of BECLIN1 with BCL-2 and BCL-xL was also indicated in single reports [42] but was not seen in our thyroid carcinoma cells as no LC3B cleavage following ABT-737 incubation was depicted.

A better sensitivity towards ABT-737 was, with the exception of FTC cell lines FTC238 and RO82W, found in FTC and PTC cell lines compared to more dedifferentiated ATC cell lines reflecting the aggressiveness and treatment resistance of ATC cells. Regarding the sensitivity towards ABT-737, it was reported that ABT-737 is effective in cells with overexpressed BCL-2, BCL-xL or BCL-w but does not bind to the anti-apoptotic proteins MCL1 or A1 [23]. Accordingly, it has been shown that an elevated expression of MCL1 or BFL-1/A1 may mediate the resistance of tumor cells to ABT-737-mediated apoptosis [36, 43]. Furthermore, the effect of ABT-737 is dependent on the expression of the pro-apoptotic proteins BAK and/or BAX which execute apoptosis when liberated from BCL-2 after ABT-737 treatment [39, 44]. In thyroid tissues, an elevated expression of BAX was demonstrated in thyroid carcinoma compared to adenoma [45]. Furthermore it was shown in different studies 
Table 3 Interaction of ABT-737 $(0.5 \mu \mathrm{M})$ with doxorubicin $(1.0 \mu \mathrm{M}$ a), gemcitbine $(0.5 \mu \mathrm{M}$ b) or cisplatin (5.0 $\mu \mathrm{M} \mathrm{c})$ in five thyroid carcinoma cell lines

\begin{tabular}{|c|c|c|c|c|}
\hline (a) Cell line & ABT-737 & Doxorubicin & ABT-737 + doxorubicin & $\mathrm{Cl}$ \\
\hline FTC236 (FTC)) & $96.2 \pm 6.5$ & $92.4 \pm 4.2$ & $68.4 \pm 5.9$ & 1.30 syn. \\
\hline ML1 (FTC) & $86.5 \pm 7.3$ & $75.9 \pm 5.4$ & $37.6 \pm 1.5$ & 1.75 syn. \\
\hline BHT101 (PTC) & $84.4 \pm 5.5$ & $90.1 \pm 6.1$ & $78.6 \pm 6.7$ & 0.97 add \\
\hline SW1736 (ATC) & $95.6 \pm 7.0$ & $74.3 \pm 4.8$ & $34.7 \pm 3.0$ & 2.05 syn. \\
\hline HTh7 (ATC) & $98.6 \pm 4.6$ & $65.0 \pm 5.5$ & $62.2 \pm 3.1$ & 1.03 add. \\
\hline (b) Cell line & ABT-737 & Gemcitabine & ABT-737 + gemcitabine & $\mathrm{Cl}$ \\
\hline FTC236 (FTC) & $99.1 \pm 4.8$ & $79.4 \pm 4.8$ & $61.3 \pm 5.0$ & 1.28 syn. \\
\hline ML1 (FTC) & $86.0 \pm 5.3$ & $83.2 \pm 5.4$ & $54.8 \pm 3.8$ & 1.31 syn. \\
\hline BHT101 (PTC) & $84.9 \pm 6.9$ & $87.6 \pm 6.7$ & $76.2 \pm 5.2$ & 0.98 add \\
\hline SW1736 (ATC) & $96.8 \pm 6.1$ & $78.5 \pm 3.8$ & $56.1 \pm 2.5$ & 1.35 syn. \\
\hline HTh7 (ATC) & $97.3 \pm 7.5$ & $71.8 \pm 4.2$ & $42.9 \pm 3.9$ & 1.63 syn. \\
\hline (c) Cell line & ABT-737 & Cisplatin & ABT-737 + cisplatin & $\mathrm{Cl}$ \\
\hline FTC236 (FTC) & $95.9 \pm 7.9$ & $102.6 \pm 9.3$ & $99.7 \pm 7.4$ & 0.99 add. \\
\hline ML1 (FTC) & $84.8 \pm 5.8$ & $97.3 \pm 7.4$ & $83.5 \pm 6.9$ & 0.99 add. \\
\hline BHT101 (PTC) & $83.4 \pm 6.3$ & $98.1 \pm 8.7$ & $81.7 \pm 5.7$ & 1.00 add. \\
\hline SW1736 (ATC) & $95.0 \pm 5.6$ & $103.8 \pm 7.2$ & $101.9 \pm 6.9$ & 0.97 add. \\
\hline HTh7 (ATC) & $99.3 \pm 7.8$ & $98.5 \pm 5.9$ & $100.2 \pm 7.0$ & 0.98 add. \\
\hline
\end{tabular}

MTT assays were performed to determine the viability of cells after incubation with one compound alone or in combination. Cl values were calculated according to the method of Drewinko et al. [34; see "Methods" section], where $\mathrm{Cl}>1.05$ indicates synergism (syn.), $0.95 \leq \mathrm{Cl} \leq 1.05$ indicates additivity (add.) and $\mathrm{Cl}<0.95$ indicates antagonism

that BCL-2 expression is strong in most differentiated thyroid carcinoma but decreases in less differentiated subtypes [46-49]. BCL-xL expression on the other hand was shown to be stronger in high-risk subtypes of thyroid carcinoma [50], while little is known about MCL1 expression in thyroid carcinoma tissues. Expression profiles of BCL-2 family proteins in our thyroid carcinoma cells was already analyzed in a recent study by our group [51]: While expression of BAK was relatively constant as a prerequisite for $\mathrm{ABT}-737$ action, $\mathrm{BAX}$ was not expressed in FTC238 and C643 and showed a weak expression in sensitive BHT101 and insensitive 8305 and 8505 cells [51]. Expression of BCL-2, BCL-xL and MCL-1 was variable [51] but not related to ABT-737 sensitivity (Table 1): The most sensitive cell line B-CPAP (IC50: $0.73 \mu \mathrm{M}$ ) showed a weak expression of both BCL-2 and BCL$\mathrm{xL}$, while MCL-1 was moderately expressed [51]. The four most sensitive cell lines besides B-CPAP (BHT101, ML1, FTC133 and TT2609) on the other hand showed a strong expression of either BCL-2 or BCL-xL and moderate expression of MCL-1 [51]. The most insensitive cell line RO82W expressed BCL-xL strongly and BCL-2 moderately [51]. In sensitive BHT101 (IC50: $1.20 \mu \mathrm{M}$ ) as well as in insensitive 8305 cells (IC50: $10.9 \mu \mathrm{M}$ ), a very low expression of both BCL-2 and BCL-xL proteins was seen [51]. Furthermore, in contrast to recent data of Iacovelli et al. [52] who showed that in five acute lymphocytic leukemia (ALL) cell lines the ratio of MCL-1/ $\mathrm{BCL}-2$ plus $\mathrm{BCL}-\mathrm{xL}$ protein ratio was correlated with sensitivity to ABT-737, in the 16 thyroid carcinoma cell lines analyzed in this study, no such correlation was found [51]. In mouse cell lines derived from thyroids of mouse strains with deleted p53 and activated Kras that develop PTC and PDTC, high expression of $\mathrm{Bcl}-2$ and $M c l 1$ was reported that mediate resistance to apoptosis [53]. These cell lines can be targeted by GX15-070 (obatoclax), a pan-inhibitor of the BCL-2 family, while ABT263 was modestly effective [53] which generally showed the suitability of $\mathrm{BH} 3$ mimetics for treatment of thyroid carcinoma cells. In one early study, Mitsiades and coworkers [54] also showed the efficacy of the BH3 inhibitors BH3I-1 and BH3I-2 in some thyroid carcinoma cell lines as well as sensitization to other anti-tumor substances [54]. In own experiments, we have recently shown the potency of GX15-070 against dedifferentiated thyroid carcinoma cells of various histological origins [51]. Treatment with GX15-070 resulted in a non-classical cell death with signs of apoptosis, autophagy and necrosis in parallel [51] that was also seen in other cell systems [5557]. While GX15-070 and its cellular targets besides the 
proteins of the BCL-2 family are not known yet, ABT-737 was shown to act as a real BH3 mimetic [23]. However, our data indicate that the expression of pro- and antiapoptotic proteins alone does not predict sensitivity to ABT-737. These results are underlined by several other recent papers: In ovarian carcinomas, it was shown that phospho-ERK1/2 as well as a low expression of BIM are biomarkers for absence of response to ABT-737 [58]. Phosphorylation of MCL-1 and BCL-2 are found to be further determinants of sensitivity to ABT-737 [59, 60]. Phosphorylation of MCL-1 at various threonine and serine residues by Cyclin E/Cdk2 kinase, ERK (extracellularsignal regulated kinase), JNK (c-jun N-terminal kinase), p38 MAPK (mitogen-activated kinase) and GSK-3 $\beta$ (glycogen synthase kinase-3 $\beta$ ) can lead to stabilization as well as destabilization of MCL-1 [59, 61-64], while phosphorylation of BCL-2 leads to a structural alteration in the BH3-binding groove and resistance to ABT-737 [60]. Furthermore, treatment of cells with ABT-737 can lead to altered expression of proteins of the BCL-2 family [65, 66]. Thus, prediction of sensitivity of a cell line to ABT737 treatment is a topic under investigation in many cell systems and also needs further investigation in thyroid carcinoma cells. However, with the availability of ABT737 and its orally active derivative ABT-263, our data on the potency of $\mathrm{BH} 3$ mimetics become a current topic.

Furthermore, facilitating cell death of cancer cells by simultaneous treatment with ABT-737 and chemotherapeutic drugs is a logical consequence of the mechanism of actions of both kinds of drugs. Since chemotherapeutic agents kill cells mainly via the mitochondrial apoptosis pathway [67] antagonists of BCL-2 proteins may influence and facilitate cell death induction by these agents. The five thyroid carcinoma cell lines examined for synergistic action of ABT-737 with chemotherapeutic agents exhibited different reaction patterns for these drug combinations: doxorubicine and gemcitabine were the most effective combinations with ABT-737 and induced synergistic effects in three or four cell lines. Papillary BHT101 cells in all combinations showed only additive effects, while cisplatin in combination with ABT-737 only had additive effects in all five cell lines (Table 3).

In other cell systems, ABT-737 was also shown to have synergistic action with other agents like cytotoxic drugs in inducing cell death like carboplatin against ovarian cancer and SCLC $[37,68]$, etoposide against SCLC [38], docetaxel against breast cancer [69] as well as kinase inhibitors like PI3 kinase and mTOR inhibitors in SCLC and colorectal cancer cells $[70,71]$. The sensitizing and apoptosis-facilitating effects for chemotherapeutic drugs by ABT-737 demonstrated here may, beyond the use of ABT-737 as single drug, be of interest as a further therapeutic option in dedifferentiated thyroid carcinomas.

\section{Conclusion}

In summary, we found that ABT-737 was effective in dedifferentiated and anaplastic thyroid carcinoma cells by inducing apoptotic cell death and furthermore showed synergistic effects with doxorubicin and gemcitabine. Although not all of the 16 cell lines examined were sensitive towards ABT-737 to the same extend, ABT-737 and related $\mathrm{BH} 3$ mimetics may have value as new therapeutic options for dedifferentiated thyroid cancer as monotherapy or in combination with other anticancer agents.

\section{Methods}

\section{Compounds and antibodies}

ABT-737 and obatoclax were from Selleck Chemicals (Houston, TX, USA). They were stored in $10 \mathrm{mM}$ aliquots in DMSO at $-20{ }^{\circ} \mathrm{C}$ and further diluted in the appropriate medium. Chemotherapeutic agents were from MerckMillipore (Darmstadt, Germany).Antibodies were from Cell Signaling Technology (Danvers, MA, USA).

\section{Cell lines and cell culture}

Established thyroid cell lines from ATC, PTC and FTC were used in this study. The SW1736, HTh7, HTh74, HTh83, C643, 8305 and 8505C cell lines were derived from ATC. BHT101, B-CPAP and TPC1 were derived from PTC. ML1, RO82W, and TT2609 are FTC cell lines. The FTC133, FTC236 and FTC238 cell lines [72] were derived from a single primary FTC, a lymph node metastasis and a lung metastasis from the same patient. HepG2 hepatocellular carcinoma cells were used as control for induction of autophagy. The HTh7 [73], HTh74 [74], HTh83 [75], C643 [76] and SW1736 [77] cell lines were a gift from Prof. Heldin (Uppsala, Sweden), and all other cell lines were purchased from ATCC (Manassas, VA, USA), ECACC (Salisbury, UK) and DSMZ (Braunschweig, Germany). Cell lines were maintained in their appropriate media supplemented with $10 \%$ fetal bovine serum (FBS, Life Technologies, Paisley, PA, USA) at $37{ }^{\circ} \mathrm{C}$ at $5 \% \mathrm{CO}_{2}$.

\section{Cell survival studies}

Depending on the cell line, $1 \times 10^{4}-5 \times 10^{4}$ cells were seeded into 96-well plates. Medium was removed after $24 \mathrm{~h}$ and replaced with culture medium without FBS but containing $0.1 \%$ bovine serum albumin (BSA) and the indicated concentrations of ABT-737, chemotherapeutic agents or a combination of both as indicated. After $48 \mathrm{~h}$, viable cells were stained with the Cell Titer Aqueous One Solution assay (Promega, Madison, WI, USA). Optical density at $490 \mathrm{~nm}$ was measured with an Emax microplate photometer (Molecular Devices, Sunnyvale, CA, USA). Control values without treatment were performed as 22-fold determinations, while all concentrations of 
ABT-737, chemotherapeutic agents and combinations were tested in eightfold. Calculation of results and Student's t test were performed using SoftMax pro software (Molecular Devices), and IC50 values were calculated using Sigma Plot software (Systat, San Jose, CA, USA). Interaction of ABT-737 with chemotherapeutic agents was calculated according to the method of Drewinko et al. [34] using the following formula: $\mathrm{Cl}=$ (survival $\mathrm{a} \times$ survival $\mathrm{b}) /($ survival $(\mathrm{a}+\mathrm{b}) \times 100)$, where $\mathrm{a}$ and $\mathrm{b}$ indicate the two drugs used and $a+b$ indicates the combination of $a$ and $b$. The interaction was interpreted on the basis of $\mathrm{Cl}$ values where $\mathrm{Cl}>1.05$ indicates synergism, $0.95 \leq \mathrm{Cl} \leq 1.05$ indicates additivity and $\mathrm{Cl}<0.95$ indicates antagonism.

\section{Measurement of lactate dehydrogenase (LDH) release and caspase $3 / 7$ activity}

Measurement of lactate dehydrogenase (LDH) released from cells with damaged membranes was performed by the CytoTox-ONE homogeneous membrane integrity assay (Promega). Determination of caspases 3 and 7 activity was done by the ApoONE homogeneous Caspase $3 / 7$ assay (Promega). $1 \times 10^{4}-5 \times 10^{4}$ cells (cell line dependent) were seeded into black, transparentbottomed 96-well plates in their appropriate growth medium. Medium was removed after $24 \mathrm{~h}$ and $100 \mu \mathrm{l} \mathrm{cul-}$ ture medium with $0.1 \%$ BSA but without FBS that contained the denoted ABT-737 concentration, was added to each well. After $24 \mathrm{~h}, 50 \mathrm{\mu l}$ of medium from each well was transferred to a fresh black 96-well plate and equilibrated to $20{ }^{\circ} \mathrm{C}$. Fifty microliter of CytoTox reagent was added, and reactions were incubated for $10 \mathrm{~min}$ in the dark at room temperature. Twenty five microliter of stop solution was added and fluorescence was determined with an excitation wavelength of $560 \mathrm{~nm}$ and an emission wavelength of $590 \mathrm{~nm}$, respectively. In each experiment, wells containing no cells as the zero setting, and fully lysed cells as the maximum LDH release control, were included. Activity of caspase 3 and 7 was determined in the original stimulation plate by adding $50 \mu \mathrm{l}$ of ApoONE reagent that contained a fluorometric caspase substrate in cell lysis and reagent buffer. After $60 \mathrm{~min}$, fluorescence was measured at $521 \mathrm{~nm}$ after excitation with $499 \mathrm{~nm}$. All values were performed as eightfold determinations. Calculation of results and Student's t tests were performed using SoftMax pro software (Molecular Devices).

\section{Cell cycle analysis}

$1 \times 10^{5}-5 \times 10^{5}$ cells per well were plated in six-well plates in their appropriate growth medium. Medium was replaced with medium without FBS but containing $0.1 \%$ BSA and $1 \mu \mathrm{M}$ ABT-737 or vehicle after $24 \mathrm{~h}$ and cells were incubated for $24 \mathrm{~h}$. Treated cells were harvested and fixed in cold $70 \%$ ethanol. RNase A $(60 \mu \mathrm{g} / \mathrm{ml})$ and propidium iodide $(25 \mu \mathrm{g} / \mathrm{ml})$ in PBS were added, and samples were incubated $20 \mathrm{~min}$ in the dark at RT. Fluorescence was measured on a FACS Calibur flow cytometer (Becton-Dickinson, San Jose, CA), and cell cycle stages were analyzed using the ModFit Software (Verity Software House, Topsham, ME, USA).

\section{Cell stimulation and protein extraction}

For ELISA and western blot analyses, cells were seeded on cell culture dishes and grown for 1-2 days until they reached $80-85 \%$ confluence. Medium was replaced with medium containing $0.1 \%$ BSA and cells were maintained in this medium for $1 \mathrm{~h}$ before $1 \mu \mathrm{M}$ ABT-737 or vehicle was added. For positive control of autophagy, HepG1 cells were incubated with $0.2 \mu \mathrm{M}$ obatoclax (GX15-070). After the indicated times, the medium was removed and collected and the cells were scraped in PBS. For cell lysis, a lysis buffer containing protease inhibitors (Complete protease inhibitor, Roche Applied Science, Mannheim, Germany) was used. The lysates were centrifugated at $10,000 \mathrm{~g}$ for $10 \mathrm{~min}$ at $4{ }^{\circ} \mathrm{C}$. The protein concentration was determined with a modified Bradford assay (Bio-Rad Laboratories, Hercules, CA, USA).

\section{Cleaved caspase and cleaved PARP ELISA}

Specific sandwich ELISAs were used to determine cleaved caspase 3 (Asp175) and cleaved poly (ADP ribose) polymerase (PARP) as a marker of apoptosis induction and protease activation (Cell Signaling Technologies) $[78,79]$. In brief, cells were plated, stimulated, and lysed as described above. Hundred microliter of diluted cell lysate containing $100 \mu \mathrm{g}$ of total protein was incubated in each of the antibody-coated well of the plate overnight at $4{ }^{\circ} \mathrm{C}$. After washing, an antibody specific for the cleaved protein and a HRP-labelled secondary antibody for detection were used. Substrate reaction was started by addition of TMB and was stopped after 30 min room temperature. Absorbance was determined at $450 \mathrm{~nm}$ (EMax microplate reader). The results were calculated as percent of unstimulated controls using SoftMax pro software (Molecular Devices).

\section{Western blot analyses}

The effects of incubation with ABT-737 or with obatoclax as the positive control on microtubule-associated protein 1A/1B-light chain 3 (LC3B) cleavage as a marker of autophagic cell death was analysed by western blot. $30 \mu \mathrm{g}$ of total protein from treated and vehicle-treated cells (see above) were denatured by boiling for $5 \mathrm{~min}$ in SDS sample buffer. Proteins were separated by SDS-PAGE 
on stain-free polyacryl amide gels (Bio-Rad Laboratories) to enable loading control $[80,81]$. After electrophoresis, optical densities of stained total proteins in each lane were documented with a CCD camera system and verified using the Quantity One software (both Bio-Rad Laboratories). When the integrated optical densities of proteins in each lane did not differ more than $10 \%$, proteins were transferred to a nitrocellulose membrane (Bio-Rad Laboratories). The blots were blocked with BSA and incubated with the LC3B primary antibody (Cell Signaling Technologies) in TBS containing $0.1 \%$ Triton X100 overnight at $4{ }^{\circ} \mathrm{C}$. An appropriate secondary antibody coupled to horseradish peroxidase was added and detection of bound antigens was performed by an enhanced chemiluminescence detection kit (Amersham ECL Advance, GE Healthcare, Piscataway, NJ, USA). Signal intensity was evaluated with a CCD-camera (Bio-Rad Laboratories).

\section{Statistical analysis}

Statistical analysis of treatment versus control groups was performed by means of the unpaired Student's t test using SPSS (IBM Inc, Armonk, NY, USA) or the other software packages indicated above. $\mathrm{P}$ values $<0.05$ were considered statistically significant.

\begin{abstract}
Abbreviations
ALL: acute lymphocytic leukemia; ATC: anaplastic thyroid carcinoma; BCL-2: B-cell lymphoma; BH3: BCL-2 homology; CLL: chronic lymphocytic leukemia; ERK: extracellular-signal regulated kinase; FTC: follicular thyroid carcinoma; GSK-3ß: glycogen synthase kinase-3ß; JNK: c-jun N-terminal kinase; LC3: microtubule-associated protein 1A/1B-light chain 3; LDH: lactate dehydrogenase; MAPK: mitogen-activated kinase; PARP: poly-(ADP-ribose)-polymerase; PDTC: poorly diferentiated thyroid carcinoma; PTC: papillary thyroid carcinoma; SCLC: small cell lung cancer.
\end{abstract}

\section{Authors' contributions}

MBP drafted the project design, planned and conducted experiments, analyzed the data and wrote the text. NBB planned and conducted experiments and discussed the data and text. SM and KM contributed to project design, text writing and discussion of the data and text. All authors read and approved the final manuscript.

\section{Author details \\ ${ }^{1}$ Department of Endocrinology and Metabolism, Division of Laboratory Research, University Hospital Essen, Hufelandstr. 55, 45122 Essen, Germany. ${ }^{2}$ Department of Nuclear Medicine, University Hospital Essen, Hufelandstr. 55, 45122 Essen, Germany. ${ }^{3}$ Present Address: Department of Clinical Chemistry, University Hospital Essen, Hufelandstr. 55, Essen, Germany. ${ }^{4}$ Present Address: Clinic of Nuclear Medicine, University Hospital Essen, Hufelandstr. 55, Essen, Germany. ${ }^{5}$ Present Address: Center of Endocrinology Alter Hof München, Dienerstr. 12, Munich, Germany.}

\section{Acknowledgements}

The authors thank Katrin Rehmann and Susanne Gall for expert technical assistance.

\section{Competing interests}

The authors declare that they have no competing interests.

Received: 2 December 2015 Accepted: 24 March 2016
Published online: 02 April 2016

\section{References}

1. Torre LA, Bray F, Siegel RL, Ferlay J, Lortet-Tieulent J, Jemal A. Global cancer statistics 2012. CA Cancer J Clin. 2015;65:87-108.

2. Xing M. Molecular pathogenesis and mechanisms of thyroid cancer. Nat Rev Cancer. 2013;13:184-99.

3. Kondo T, Ezzat S, Asa SL. Pathogenetic mechanisms in thyroid follicularcell neoplasia. Nat Rev Cancer. 2006;6:292-306.

4. Kapiteijn E, Schneider TC, Morreau H, Gelderblom H, Nortier JWR, Smit JWA. New treatment modalities in advanced thyroid cancer. Ann Oncol. 2006;23:10-8.

5. Baudin E, Schlumberger M. New therapeutic approaches for metastatic thyroid carcinoma. Lancet Oncol. 2007;8:148-56.

6. Eustatia-Rutten CF, Corssmit EP, Biermasz NR, Pereira AM, Romijn JA, Smit JW. Survival and death causes in differentiated thyroid carcinoma. J Clin Endocrinol Metab. 2006:91:313-9.

7. Smallridge RC, Marlow LA, Copland JA. Anaplastic thyroid cancer: molecular pathogenesis and emerging therapies. Endocr Rel Cancer. 2009;16:17-44.

8. Volante M, Rapa I, Papotti M. Poorly differentiated thyroid carcinoma: diagnostic features and controversial issues. Endocr Pathol. 2008;19:150-5.

9. Sherman SI. Advances in chemotherapy of differentiated epithelial and medullary thyroid cancers. J Clin Endocrinol Metab. 2009;94:1493-9.

10. Schlumberger M, Sherman SI. Approach to the patient with advanced differentiated thyroid cancer. Eur J Endocrinol. 2012;166:5-11.

11. Johnstone RW, Ruefli AA, Lowe SW. Apoptosis: a link between cancer genetics and chemotherapy. Cell. 2002;108:153-64.

12. Hanahan D, Weinberg RA. Hallmarks of cancer: the next generation. Cell. 2011;144:646-74.

13. Long JS, Ryan KM. New frontiers in promoting tumour cell death: targeting apoptosis, necroptosis and autophagy. Oncogene. 2012;31:5045-60.

14. Galluzzi L, Vitale I, Abrams JM, Alnemri ES, Baehrecke EH, Blagosklonny MV, Dawson TM, Dawson VL, El-Deiry WS, Fulda S, Gottlieb E, Green DR, Hengartner MO, Kepp O, Knight RA, Kumar S, Lipton SA, Lu X, Madeo F, Malorni W, Mehlen P, Nunez G, Peter ME, Piacentini M, Rubinsztein DC, Shi Y, Simon H-U, Vandenabeele P, White E, Yuan J, Zhivitivsky B, Melino G, Kroemer G. Molecular definitions of cell death subroutines: recommendations of the nomenclature committee on cell death 2012. Cell Death Differ. 2012;19:107-20.

15. Budihardjo I, Oliver H, Lutter M, Luo X, Wang X. Biochemical pathways of caspase activation during apoptosis. Annu Rev Cell Dev Biol. 1999;15:269-90.

16. Vandenabeele P, Galluzzi L, Vanden Berghe T, Kroemer G. Molecular mechanisms of necroptosis: an ordered cellular explosion. Nat Rev Mol Cell Biol. 2010;11:700-14.

17. He S, Wang L, Miao L, Wang T, Du F, Zhao L, Wang X. Receptor interacting protein kinase-3 determines cellular necrotic response to TNF-alpha. Cell. 2009;137:1100-11

18. Choi AMK, Ryter SW, Levine B. Autophagy in human health and disease. New Engl J Med. 2013;368:651-62.

19. Lessene G, Czabotar PE, Colman PM. Bcl-2 family antagonists for cancer therapy. Nature Rev Drug Discov. 2008;7:989-1000.

20. Tait SW, Green DR. Mitochondria and cell death: outer membrane permeabilization and beyond. Nat Rev Mol Cell Biol. 2010;11:621-32.

21. Cory S, Adams JM. Killing cancer cells by flipping the $\mathrm{BCl}-2 / \mathrm{Bax}$ switch. Cancer Cell. 2005;8:5-6.

22. Azmi AS, Mohammad RM. Non-peptidic small molecule inhibitors against bcl-2 for cancer therapy. J Cell Physiol. 2009:218:13-21.

23. Oltersdorf T, Elmore SW, Shoemaker AR, Armstrong RC, Augeri DJ, Belli BA, Bruncko M, Deckwerth TL, Dinges J, Hajduk PJ, Joseph MK, Kitada S, Korsmeyer SJ, Kunzer AR, Letai A, Li C, Mitten MJ, Nettesheim DG, Ng SC, Nimmer PM, O'Connor JM, Oleksijew A, Petros AM, Reed JC, Shen W, Tahir SK, Thompson CB, Tomaselli KJ, Wang B, Wendt MD, Zhang H, Fesik SW, Rosenberg $\mathrm{SH}$. An inhibitor of $\mathrm{BCl}-2$ family proteins induces regression of solid tumors. Nature. 2005:435:677-81.

24. Van Delft MF, Wei AH, Mason KD, Vandenberg CJ, Chen L, Czabotar PE, Willis SN, Scott CL, Day CL, Cory S, Adams JM, Roberts AW, Huang DC. 
The $\mathrm{BH} 3$ mimitic ABT-373 targets selective $\mathrm{BCl}-2$ proteins and efficiently induces apoptosis via Bak/Bax if $\mathrm{Mcl}-1$ is neutralized. Cancer Cell. 2006;10:389-99.

25. Tse C, Shoemaker AR, Adickes J, Anderson MG, Chen J, Jin S, Johnson EF, Marsh KC, Mitten MJ, Nimmer P, Roberts L, Tahir SK, Xiao Y, Yang X, Zhang H, Fesik S, Rosenberg SH, Elmore SW. ABT-263: a potent and orally bioavailable Bcl-2 family inhibitor. Cancer Res. 2008;68:3421-8.

26. Wilson WH, O'Connor OA, Czuczman MS, LaCasce AS, Gerecitano JF, Leonard JP, Tulpule A, Dunleavy K, Xiong H, Chiu YL, Cui Y, Busman T, Elmore SW, Rosenberg SH, Krivoshik AP, Enschede SH, Humerickhouse RA. Navitoclax a targeted high-affinity inhibitor of BCL-2, in lymphoid malignancies: a phase 1 dose-escalation study of safety, pharmacokinetics, pharmacodynamics, and antitumour activity. Lancet Oncol. 2010;11:1149-59.

27. Roberts AW, Seymour JF, Brown JR, Wierda WG, Kipps TJ, Khaw SL, Carney DA, He SZ, Huang DC, Xiong H, Cui Y, Busman TA, McKeegan EM, Krivoshik AP, Enschede SH, Humerickhouse R. Substantial susceptibility of chronic lymphocytic leukemia to BCL2 inhibition: results of a phase I study of navitoclax in patients with relapsed or refractory disease. J Clin Oncol. 2012;30:488-96.

28. Gandhi L, Camidge DR, Ribeiro de Oliveira M, Bonomi P, Gandara D, Khaira D, Hann CL, McKeegan EM, Litvinovich E, Hemken PM, Dive C, Enschede SH, Nolan C, Chiu YL, Busman T, Xiong H, Krivoshik AP, Humerickhouse R, Shapiro Gl, Rudin CM. Phase 1 study of Navitoclax (ABT-263), a novel BCl-2 family inhibitor, in patients with small-cell lung and other solid tumors. J Clin Oncol. 2010;29:909-16.

29. Kipps TJ, Eradat H, Grosicki S, Catalano J, Cosolo W, Dyagil IS, Yalamanchili S, Chai A, Sahasranaman S, Punnoose E, Hurst D, Pylypenko H. A phase 2 study of the $\mathrm{BH} 3$ mimetic BCL2 inhibitor navitoclax (ABT-263) with or without rituximab, in previously untreated B-cell chronic lymphocytic leukemia. Leuk Lymphoma. 2015;12:1-8.

30. Xiong H, Pradhan RS, Nada A, Krivoshik AP, Holen KD, Rhodes JW, Gordon GB, Humerickhouse R, Awni WM. Studying navitoclax, a targeted anticancer drug, in healthy volunteers-ethical considerations and risk/benefit assessments and management. Anticancer Res. 2014;34:3739-46.

31. Schweppe RE, Klopper JP, Korch C, Pugazhenthi U, Benezra M, Knauf JA, Fagin JA, Marlow LA, Copland JA, Smallridge RC, Haugen B. Desoxyribonucleic acid profiling analysis of 40 human thyroid cancer cell lines reveals cross-contamination resulting in cell line redundancy and misidentification. J Clin Endocrinol Metab. 2008;93:4331-41.

32. Broecker-Preuss M, Müller S, Britten M, Worm K, Schmid KW, Mann K, Fuhrer D. Sorafenib inhibits intracellular signaling pathways and induces cell cycle arrest and cell death in thyroid carcinoma cells irrespective of histological origin or BRAF mutational status. BMC Cancer. 2015;15:184.

33. Su JC, Tseng PH, Hsu CY, Tai WT, Huang JW, Ko CH, Lin MW, Liu CY, Chen KF, Shiau CW. RFX-dependent activation of SHP-1 induces autophagy by a novel obatoclax derivative in hepatocellular carcinoma cells. Oncotarget. 2014;5:4909-19.

34. Drewinko B, Loo TL, Brown JA, Gottlieb JA, Freireich EJ. Combination chemotherapy in vitro with adriamycin. Observations of additive, antagonistic and synergistic effects when used in two-drug combination on cultured human lymphoma cells. Cancer Biochem Biophys. 1976;1:187-95.

35. Letai A, Bassik MC, Walensky LD, Sorcinelli MD, Weiler S, Korsmeyer SJ. Distinct $\mathrm{BH} 3$ domains either sensitize or activate mitochondrial apoptosis, serving as prototype cancer therapeutics. Cancer Cell. 2002;3:183-92.

36. Deng J, Carlson N, Takeyama K, Dal Cin P, Shipp M, Letai A. BH3 profiling identifies three distinct classes of apoptotic blocks to predict response to ABT-737 and conventional chemotherapeutic agents. Cancer Cell. 2007; 12:171-85

37. Tahir SK, Yang X, Anderson MG, Morgan-Lappe SE, Sarthy AV, Chen J, Warner RB, Ng SC, Fesik SW, Elmore SW, Rosenberg SH, Tse C. Influence of $\mathrm{BCl}-2$ family members on the cellular response of small-cell lung cancer cell lines to ABT-737. Cancer Res. 2007;67:1176-83.

38. Hann CL, Daniel VC, Sugar EA, Dobromilskaya I, Murphy SC, Cope L, Lin X, Hierman JS, Wilburn DL, Watkins DN, Rudin CM. Therapeutic efficacy of ABT-737, a selective inhibitor of BCL-2, in small cell lung cancer. Cancer Res. 2008;68:3421-8.

39. Chen S, Dai Y, Harada H, Dent P, Grant S. Mcl-1 down-regulation potentiates ABT-737 lethality by cooperatively inducing bak activation and bax translocation. Cancer Res. 2007;67:782-91.
40. Tagscherer KE, Fassl A, Campos B, Farhadi M, Kraemer A, Böck BC, MacherGoeppinger S, Radlwimmer B, Wiestler OD, Herold-Mende C, Roth W. Apoptosis-based treatment of glioblastomas with ABT-737, a novel small molecule inhibitor of Bcl-2 family proteins. Oncogene. 2008;27:6646-56.

41. Del Gaizo Moore V, Brown JR, Certo M, Love TM, Novina CD, Letai A. Chronic lymphocytic leukemia requires $B C L 2$ to sequester prodeath BIM, explaining sensitivity to BCL2 antagonst ABT-737. J Clin Invest. 2007;117:112-21.

42. Maiuri MC, Criollo A, Tasdemir E, Vicencio JM, Tajeddine N, Hickman JA, Geneste $\mathrm{O}$, Kroemer G. BH3-only proteins and $\mathrm{BH} 3$ mimetics induce autophagy by competitively disrupting the interaction between beclin 1 and $\mathrm{BCl}-2 / \mathrm{BCl}-\mathrm{X}(\mathrm{L})$. Autophagy. 2007;3:374-6.

43. Certo M, Del Gaizo Moore V, Nishino M, Wei G, Korsmeyer S, Armstrong SA, Letai A. Mitochondria primed by death signals determine cellular addiction to antiapoptotic BCL-2 family members. Cancer Cell. 2006;9:351-65.

44. Cragg MS, Harris C, Strasser A, Scott CL. Unleashing the power of inhibitors of oncogenic kinases through $\mathrm{BH} 3$ mimetics. Nat Rev Cancer. 2009:9:321-6.

45. Hermann S, Sturm I, Mrozek A, Klosterhalfen B, Hauptmann S, Dörken $B$, Daniel PT. BAX expression in benign and malignant thyroid tumours: dysregulation of wild-type p53 is associated with a high bax and P21 expression in thyroid carcinoma. Int J Cancer. 2001;92:805-11.

46. Saltmann B, Singh B, Hedvat CV, Wreesmann VB, Ghossein R. Patterns of expression of cell cycle/apoptosis genes along the spectrum of thyroid carcinoma progression. Surgery. 2006;140:899-905.

47. Soda G, Antonaci A, Bosco D, Nardoni S, Melis M. Expression of bcl-2, c-erbB-2, p53, and p21 (waf1-cip1) protein in thyroid carcinomas. J Exp Clin Cancer Res. 1999;18:363-7.

48. Haynik DM, Prayson RA. Immunohistochemical expression of $\mathrm{BCl}-2, \mathrm{BCl}-\mathrm{x}$ and Bax in follicular carcinomas of the thyroid. Appl Immunohistochem Mol Morphol. 2006;14:417-21.

49. Cvejic D, Selemetjev S, Savin S, Paunovic I, Tatic S. Changes in the balance between proliferation and apoptosis during the progression of malignancy in thyroid tumours. Eur J Histochem. 2009;53:65-72.

50. Martinez-Brocca MA, Castilla C, Navarro E, Amays MJ, Travado P, Japón MA, Sáez C. Clinicopathological correlations of BCl-xL and Bax expression in differentiated thyroid carcinoma. Clin Endocrinol. 2008;68:190-7.

51. Broecker-Preuss M, Viehof J, Jastrow H, Becher-Boveleth N, Fuhrer D, Mann K. Cell death induction by the BH3 mimetic GX15-070 in thyroid carcinoma cells. J Exp Clin Cancer Res. 2015;34:69.

52. lacovelli S, Ricciardi MR, Allegretti M, Mirabilii S, Licchetta R, Bergamo P, Rinaldo C, Zeuner A, Foà R, Milella M, McCubrey JA, Martelli AM, Tafuri A. Co-targeting of $\mathrm{BCl}-2$ and mTOR pathway triggers synergistic apoptosis in $\mathrm{BH} 3$ mimetics resistant acute lymphoblastic leukemia. Oncotarget. 2015;6:32089-103.

53. Champa D, Russo MA, Liao X-H, Refetoff S, Ghossein RA, Di Christofano A. Obatoclax overcomes resistance to cell death in aggressive thyroid carcinomas by countering Bcl2a1 and Mcl1 overexpression. Endocr Rel Cancer. 2014;21:755-67.

54. Mitsiades CS, Hayden P, Kotoula V, McMilin DW, McMullan C, Negri J, Delmore JE, Poulaki V, Mitsiades N. BCl-2 overexpression in thyroid carcinoma cells increases sensitivity to bcl-2 homology 3 domain inhibition. J Endocrinol Metab. 2007;92:4845-52.

55. McCoy F, Hurwitz J, McTavish N, Paul I, Barnes C, O’Hagan B, Odrzywol K, Murray J, Longley D, McKerr G, Fennell DA. Obatoclax induces ATG7dependent autophagy independent of beclin-1 and BAX/BAK. Cell Death Dis. 2010;1:e108.

56. Vogler M, Weber K, Dinsdale D, Schmitz, Schulze-Osthoff K, Dyer MJS, Cohen GM. Different forms of cell death induced by putative BCL2 inhibitors. Cell Death Differ. 2009;16:1030-9.

57. Albershardt TC, Salerni BL, Soderquist RS, Bates CJP, Pletnev AA, Kisslev AF, Eastman A. Multiple BH3 mimetics antagonize antiapoptotic mcl1 protein by inducing the endoplasmic reticulum stress response and upregulating BH3-only protein noxa. J Biol Chem. 2011;286:24882-95.

58. Lheureux S, N'Diaye M, Blanc-Fournier C, Dugué AE, Clarisse B, Dutoit S, Giffard F, Abeilard E, Briand M, Labiche A, Grellard JM, Crouet H, Martin $\mathrm{S}$, Joly F, Poulain L. Identification of predictive factors of response to the BH3-mimetic molecule ABT-737: an ex vivo experiment in human serous ovarian carcinoma. Int J Cancer. 2015;136:E340-50.

59. Choudhary GS, Tat TT, Misra S, Hill BT, Smith MR, Almasan A, Mazumder S. Cyclin E/Cdk2-dependent phosphorylation of Mcl-1 determines its stability and cellular sensitivity to BH3 mimetics. Oncotarget. 2015;6:16912-25. 
60. Song T, Chai G, Liu Y, Yu X, Wang Z, Zhang Z. Bcl-2 phosphorylation confers resistance of chronic lymphocytic leukemia cells to the $\mathrm{BH} 3$ mimetic ABT-737, ABT-263 and ABT-199 by impeding direct binding. Br J Pharmacol. 2016;173:471-83.

61. Opferman JT. Unraveling MCL-1 degradation. Cell Death Differ. 2006;13:1260-2

62. Morel C, Carlson SM, White FM, Davis RJ. Mcl-1 integrates the opposing actions of signaling pathways that mediate survival and apoptosis. Mol Cell Biol. 2009;14:3845-52.

63. Nifoussi SK, Vrana JA, Domina AM, De Biasio A, Gui J, Gregory MA, Hann SR, Craig RW. Thr 163 phosphorylation causes Mcl-1 stabilization when degradation is independent of the adjacent GSK3-targeted phosphodegron, promoting drug resistance in cancer. PLoS One. 2012;7:e47060.

64. Maurer U, Charvet C, Wagman AS, Dejardin E, Green DR. Glycogen synthase kinase-3 regulates mitochondrial outer membrane permeabilization and apoptosis by destabilization of MCL-1. Mol Cell. 2006;21:749-60.

65. Hoffman-Luca CG, Ziazadeh D, McEachern D, Zhao Y, Sun W, Debussche L, Wang S. Elucidation of acquired resistance to $\mathrm{BCl}-2$ and MDM2 inhibitors in acute leukemia in vitro and in vivo. Clin Cancer Res. 2015;21:2558-68.

66. Wroblewski D, Jiang CC, Croft A, Farrelly ML, Zhang XD, Hersey P. OBATOCLAX and ABT-737 induce ER stress responses in human melanoma cells that limit induction of apoptosis. PLoS One. 2013:8:e84073.

67. Portugal J, Bataller M, Mansilla S. Cell death pathways in response to antitumor therapy. Tumori. 2009;95:409-21.

68. Witham J, Valenti MR, De-Haven-Brandon AK, Vidot S, Eccles SA, Kaye SB, Richardson $\mathrm{A}$. The $\mathrm{BCl}-2 / \mathrm{BCl}-\mathrm{XL}$ family inhibitot $\mathrm{ABT}-737$ sensitizes ovarian cancer cells to carboplatin. Clin Cancer Res. 2007;13:7191-8.

69. Oakes SR, Vaillant F, Lim E, Lee L, Breslin K, Feleppa F, Deb S, Ritchie ME, Takano E, Ward T, Fox SB, Generali D, Smyth GK, Strasser A, Huang DCS, Visvader JE, Lindeman GJ. Sensitization of BCL-2-expressing breast tumors to chemotherapy by the BH3 mimetic ABT-737. Proc Natl Acad Sci USA. 2012;109:2766-71.

70. Potter DS, Kelly P, Denneny O, Juvin V, Stephens LR, Dive C, Morrow CJ. $\mathrm{BMX}$ acts downstream of PI3K to promote colorectal cancer cell survival and pathway inhibition sensitizes to the $\mathrm{BH} 3$ mimetic ABT-737. Neoplasia. 2014;16:147-57

71. Gardner EE, Connis N, Poirier JT, Cope L, Dobromilskaya I, Gallia GL, Rudin CM, Hann CL. Rapamycin rescues ABT-737 efficacy in small cell lung cancer. Cancer Res. 2014;74:2846-56.
72. Goretzki PE, Frilling A, Simon D, Rastegar M, Ohmann C. Growth regulation of human thyrocytes by thyrotropin, cyclic adenosine monophosphate, epidermal growth factor and insulin-like growth factor. Front Horm Res Basel Karger. 1989;18:56-80.

73. Carlson J, Nilsson K, Westermark B, Ponten J, Sundstöm C, Larsson E, Bergh J, Pahlman S, Busch C, Collins VP. Formation and growth of multicellular spheroids of human origin. Int J Cancer. 1983;31:523-33.

74. Heldin NE, Cvejic D, Smeds S, Westermark B. Coexpression of functionally active receptors for thyrotropin and platelet-derived growth factor in human thyroid carcinoma cells. Endocrinology. 1991;129:2187-93.

75. Dahlman T, Lammerts E, Wik M, Bergström D, Grimelius L, Westermark K, Rubin K, Heldin NE. Fibrosis in undifferentiated (anaplastic) thyroid carcinomas: evidence for a dual action of tumour cells in collagen type I synthesis. J Pathol. 2000;191:376-86.

76. Heldin NE, Gustavson B, Claesson-Welsh L, Hammacher A, Mark J, Heldin $\mathrm{CH}$, Westermark B. Aberrant expression of receptors for PDGF in an anaplastic thyroid carcinoma cell lines. Proc Natl Acad Sci USA. 1988;85:9302-6

77. Mark J, Ekedahl C, Dahlenfors R, Westermark B. Cytogenetical observations in five human anaplastic thyroid carcinomas. Hereditas. 1987; 107:163-74

78. Chen X, Iliopoulos D, Zhang Q, Tang Q, Greenblatt MB, Hatziapostolou M, Lim E, Tam WL, Ni M, Chen Y, Mai J, Shen H, Hu DZ, Adoro S, Hu B, Song M, Tan C, Landis MD, Ferrari M, Shin SJ, Brown M, Chang JC, Liu XS, Glimcher LH. XBP1 promotes triple-negative breast cancer by controlling the HIF1a pathway. Nature. 2014;508:103-7.

79. Levy DS, Kahana JA, Kumar R. AKT inhibitor, GSK690693, induces growth inhibition and apoptosis in acute lymphoblastic leukemia cell lines. Blood. 2009;113:1723-9.

80. Rivero-Gutiérrez B, Anzola A, Martínez-Augustin O, de Medina FS. Stainfree detection as loading control alternative to Ponceau and housekeeping protein immunodetection in Western blotting. Anal Biochem. 2014;467:1-3.

81. Gilda JE, Gomes AV. Stain-Free total protein staining is a superior loading control to $\beta$-actin for Western blots. Anal Biochem. 2013;440:186-8.

\section{Submit your next manuscript to BioMed Central and we will help you at every step:}

- We accept pre-submission inquiries

- Our selector tool helps you to find the most relevant journal

- We provide round the clock customer support

- Convenient online submission

- Thorough peer review

- Inclusion in PubMed and all major indexing services

- Maximum visibility for your research

Submit your manuscript at www.biomedcentral.com/submit

\section{() Biomed Central}

